\title{
Left atrial volume and exercise capacity in adult heart transplant recipients
}

\author{
Vitor Oliveira Carvalho
}

\section{Letter to the editor}

It is well established that heart transplantation can improve patients' quality of life, exercise capacity and survival $[1,2]$. Despite of the improvement in exercise performance after heart transplant, it still remains subnormal when compared with healthy subjects [3]. Cardiac causes as chronotropic incompetence [4] and diastolic dysfunction [5] have been proposed to be related to the post-transplant exercise impairment, but few studies are available about this theme.

The study by Abdul-Waheed et al. [6] is very interesting and adds important information to what we know about cardiac causes of exercise capacity limitations in heart transplant recipients. This retrospective study investigated the left atrial volume (LAV, $\mathrm{n}=50)$ and its change along one year $(\triangle \mathrm{LAV}, \mathrm{n}=40)$ in transplant recipients.

The main find of the study by Abdul-Waheed et al was the increasing of the LAV along the one year follow-up and the modest correlation between LAV $(\mathrm{r}=$ $0.3 ; \mathrm{p}=0.038)$ and $\Delta \mathrm{LAV}(\mathrm{r}=0.48 ; \mathrm{p}=0.002)$ with VE/ $\mathrm{VCO}_{2}$ slope, what made the authors speculate about the surgical scar between the native and donor atrium. This scar could impair left atrial pump function and induce atrium dilatation to increase its capacity, as a compensatory mechanism.

In the figure one of the study, it is evident that some patients decreased LAV while the greatest part of patients increased LAV along the follow-up. Maybe if the authors have made the correlation between the $\triangle \mathrm{LAV}$ and $\mathrm{VE} / \mathrm{VCO}_{2}$ slope separately, according to the increasing or decreasing of the LAV along the followup, it could be figured out that patients who had a decreased LAV could have experienced a negative correlation between $\triangle \mathrm{LAV}$ and $\mathrm{VE} / \mathrm{VCO}_{2}$ slope.

\footnotetext{
Correspondence: vitor.carvalho@usp.br
}

Laboratório de Insuficiência Cardíaca e Transplante do Instituto do Coração do Hospital das Clínicas da Faculdade de Medicina da USP (InCor HC-FMUSP), São Paulo, Brazil
This way, these data suggest that LAV may play an important role on the exercise capacity understanding in heart transplant recipients.

Received: 1 January 2011 Accepted: 19 January 2011 Published: 19 January 2011

\section{References}

1. Wu YT, Chien CL, Chou NK, Wang SS, Lai JS, Wu YW: Efficacy of a homebased exercise program for orthotopic heart transplant recipients. Cardiology 2008, 111:87-93

2. Carvalho VO, Bocchi EA, Guimarães GV: Aerobic Exercise Prescription in Adult Heart Transplant Recipients: A Review. Cardiovasc Ther 2010, doi: 10.1111/j.1755-5922.2010.00175.x.

3. Leung TC, Ballman KV, Allison TG, Wagner JA, Olson LJ, Frantz RP, et al: Clinical predictors of exercise capacity 1 year after cardiac transplantation. J Heart Lung Transplant 2003, 22:16-27.

4. Bengel FM, Ueberfuhr P, Schiepel N, Nekolla SG, Reichart B, Schwaiger M: Effect of sympathetic reinnervation on cardiac performance after heart transplantation. N Engl J Med 2001, 345:731-8.

5. Paulus WJ, Bronzwaer JG, Felice $H$, Kishan N, Wellen F: Deficient acceleration of left ventricular relaxation during exercise after heart transplantation. Circulation 1992, 86:1175-85.

6. Abdul-Waheed M, Yousuf M, Kelly SJ, Arena R, Ying J, Naz T, Dunlap SH, Shizukuda Y: Does left atrial volume affect exercise capacity of heart transplant recipients? J Cardiothorac Surg 2010, 5:113.

doi:10.1186/1749-8090-6-9

Cite this article as: Carvalho: Left atrial volume and exercise capacity in adult heart transplant recipients. Journal of Cardiothoracic Surgery 2011 6:9.

\section{Submit your next manuscript to BioMed Central and take full advantage of:}

- Convenient online submission

- Thorough peer review

- No space constraints or color figure charges

- Immediate publication on acceptance

- Inclusion in PubMed, CAS, Scopus and Google Scholar

- Research which is freely available for redistribution

Submit your manuscript at www.biomedcentral.com/submit

\section{Biomed Central}

